Boldasu, R. (2020). Theatre Semiotics in the 21st century. 21st century: history and modernity of art. Collection of Scientific Articles. European Scientific e-Journal, 4 (4), 54-63. Hlučín-Bobrovníky: "Anisiia Tomanek" OSVČ.

Boldaşu, R. (2020). Semiotică Teatrală în secolul al XXI-lea. 21st century: bistory and modernity of art. Collection of Scientific Articles. European Scientific e-Journal, 4 (4), 54-63. Hlučín-Bobrovníky: "Anisiia Tomanek" OSVČ.

DOI: $10.47451 / \operatorname{art} 2020-11-004$

EOI: $10.11244 / \operatorname{art} 2020-11-004$

The paper is published in Crossref, Internet Archive, Google Scholar, Academic Resource Index ResearchBib, JGate, ISI, CiteFactor, ICI, eLibrary databases.

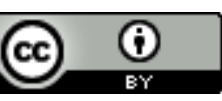

Romina Boldasu

Associate Professor

Acting Department

National University of Theatre and Film "I.L. Caragiale"

Bucharest, Romania

E-mail: romina.boldasu@unatc.ro

\title{
Theatre Semiotics in the 21st century
}

\section{Abstract:}

The role of the actor has been in continuous change across time. Therefore, the teaching paradigm needs to be transformed in order to meet the 21 st century needs and interests. Theatre is not only an aesthetic tool in contemporary society but also an instrument in transmitting social, political and cultural information. The body of the actor contains within itself a system of verbal and non-verbal communication mechanisms that one must master in order to create dialogue across the globe. The author concludes that in the contemporary world, countless systems of communication are integrated which are subject to interpretation. Spoken language can be interpreted differently by people from different cultural contexts; that is why, through the training proposed in the present research, the actor can communicate and interact freely, without fear of being misunderstood through body language.

\section{Keywords:}

theatre, art, acting communication, embodiment, physical, training, gesture, language, system, culture, expressivity, human dynamics.

Romina Boldaşu

Profesor asociat doctor Departamentul Arta Actorului Universitatea Națională de Arta Teatrală şi Cinematografică Bucureşti, România E-mail: romina.boldasu@unatc.ro 


\section{Semiotică Teatrală în secolul al XXI-lea}

Abstract:

Rolul actorului s-a schimbat de-a lungul timpului. Astfel paradigma de predare trebuie de asemenea să se transforme pentru a întâlni nevoile și interesele propuse de secolul al XXI-lea. În societatea contemporană, teatrul nu este doar un instrument estetic ci un vector în transmiterea mesajelor sociale, politice și culturale. În corpul actorului sunt conținute mecanisme de comunicare atât verbale cât și nonverbale pe care acesta trebuie să le stăpânească cu măiestrie pentru a crea un dialog global. Autorul ajunge la concluzia că în lumea modernă există nenumărate sisteme integrate de comunicații care sunt supuse interpretării. Limbajul vorbit poate fi interpretat în moduri diferite de către oameni din contexte culturale diferite; Acesta este motivul pentru care, datorită învățăturii oferite în acest studiu, actorul poate comunica și interacționa liber fără teama de a nu fi înțeles greșit de limbajul corpului.

\section{Cuvinte cheie:}

teatru, artă, actorie, comunicare, corporalizare, fizic, antrenament, gest, limbaj, sistem, cultură, expresivitate, dinamica umană.

\section{Introduction}

The art of theatre, throughout time, has undergone a trajectory of evolution and transformation in order to meet the need of humanness. Society has gradually changed its rules of functioning. This fact has generated the metamorphosis of theatrical manifestations with a view to continue the process proposed by the social and political order or, on the contrary, in order to distance itself from these imposed rules.

The artist has always been regarded as the one with the courage to eliminate the rule, to oppose concepts governed by the cannon of ought to. The attitude towards the art of theatre has transformed over centuries and with it the performance spaces have changed, along with the power of the dramatic art to have any influence in the world. The body of the actor remained a constant despite the changes that occurred, it's only the way it is perceived that has altered. This is an opportunity for the theatrical researcher and the contemporary artist to study the rapport between the actor's body and the world with a view to concoct a training that is adequate to the situation and the function of the art of theatre and of the 21 st century. The individual functions based on the connections between systems, as a mechanism would. In the study of human dynamics, an intersection in the analysis of the psycho-physical systems takes place.

\section{The study material}


The techniques which refer to the development of specific attitudes of actors using their body as a trigger, such as the one based on individual somatic (Eugenio, 2003), were formulated long ago in institutions and theatrical research centres all over the world. The study of the actor's art involves a careful and applied investigation of human behaviour. Desmond Morris claims, "As a species, we can evolve technically and philosophically, but we have not lost the animal characteristics of being physically active." (Desmond, 2002) He analyses in detail the evolution of the human species, starting from the investigation of the way in which the human being acts. Morris spots in each corporeal action a repetitive sequence (posture - movement) and a pattern typical of corporeal unity named fixed action pattern. The human body, created millions of years ago, developed movement patterns. The analysis of these patterns both historically, anthropologically, and scientifically, helps the actor understand human behaviour.

Knowing the way, in which an individual acts are, the process of transformation of the gesture in action and then back into physical dramatical action allows the actor to shape their existence with more certainty both on stage as well as in the rehearsal room. The analysis of animal rituals, e.g., can inspire an actor in the development of their corporeal vocabulary and helps them understand behavioural reactions of people, such as selflessness. Desmond Morris analyses where the idea of self is situated in an individual's selfless actions, since "as human beings are animals whose predecessors won the fight for survival throughout the history of evolution, they cannot be genetically scheduled to display sincere selflessness" (Desmond, 2002) and yet people do act this way. A researcher, biologist, painter and author of the well-known study on the evolution of human over time, The Naked Ape (Desmonds, 1967), he sees the body as a container carrying the genetic peculiarities of the past generation. Thus, the human is the one who tries to protect this valuable content from self-destructing over its lifetime.

This view, borrowed by the actor, determines them to treat the body not just as an action vector, but as a system connecting the past to the present. Through selfless behaviour, which is the most visible within the human physical action, humans managed over time to survive climate change, attacks form other species, and natural disasters. The care towards one's peers lead to the construction of a functioning structure in which the individual would obey the rule of the group and at the same time, would take care of their own existence. Explaining human behaviour paves the way for defining the art of theatre. Vakhtangov supports the idea of theatre as a group art, as "a brilliant actor 
is not theatre; they are a monster, a miracle. To prefer a good actor instead of an entire company means to negate the very essence of theatre; the concept of theatre includes the notion of collective" (Malaev-Babel, 2011). In the analysis of the actor's body in different environments and situations, we propose that they be observed not privately, but in the course of collateral training. Empathy, as a physiological group process, can also be observed on bodily level.

In the context of the technological world, the work methodology of the actor must contain this link between scientific and technical analysis and the one of a creative, empirical nature. Stanislavsky applies psychological principles in theatre in an original manner: "The Psychotechnique, the mental technique that Stanislavsky summed up in the term 'perejvanie', is not limited to the actor identifying themselves with the presumed feelings and emotional states of the character. It can, of course, be used with the purpose of offering to the spectator's gaze a 'verisimilitude effect', the illusion of witnessing a real slice of life. But it brings up a general and essential issue: no matter what the aesthetics of staging, there must be a rapport between the score of physical actions and the 'under-score', the benchmarks, the inner mobilisation of the actor. It is, in other words, the issue of the body-spirit, of the psycho-physical global-ness of action." (Martha, 2009) The problematics of the body is analysed in the context of the development of work systems that function on a unitary as opposed to a fragmentary level. The effect of verisimilitude that Eugenio Barba talks about is conveyed through the means of the body both on a sensorial, as well as on a neuronal and physical level.

Mihai Ralea, in his description of the model of the successful person, suggests that "another element, which is favourable to the access of a personality on the success ladder and which depends upon the individual, is a psychological aptitude which consists of long-lasting patience, of tenacity, of the will with which they pursue something." (Ralea, 1972) A successful actor trains this ability during the training hours proposed by the present research. The capacity to be resilient to change, to adapt to novelty only in order to function artistically, the patience to work with partners and the availability to understand them are elements that can be developed along with the concentration of attention on the body of the individual. The aesthetician also defines the term "expressivity" as the quality of an individual having a "will to influence, to communicate, which often becomes a propaganda, and to display, to isolate one thing, to frame it so that all the look of society would converge on it" (Ralea, 1972). 
The term "expressivity" thus suggests the idea of an individual who is capable of manipulating, charming, coordinating a group with a view to them adhering to a unanimous belief. The emergence of the term Physical Theatre, approximately thirty years ago, generates a change in the discourse on the art of theatre. Even though it was not called that in the past, the concept of physical theatre is approached by militants of new forms of theatre such as Brecht, Meyerhold, or Artaud. Peter Brook, mentioned by Simon Murray and John Keffe in their critical work on physical theatre as a method of combining classical theatre and dance, state that "being physical in theatre means, apparently, being progressive, fresh, current, risqué" (Brook et al., 2016). Also, physical theatre implies the distancing from the old forms of theatre, static theatre, called "dead" by Peter Brook. The new approach in decrypting and developing the 21 st century actor is based upon an interdisciplinary vision, which involves both connecting arts, as well as exact sciences, such as medical research, sports, and even neuroscience. If the relationship between the dramatic text and the performance composition diminishes due to the emergence of the new forms of language, of movements and gestures, then the phrasing of a new work strategy is in order. The nature of the actor's body must be modified, updated, just like a software, with a view to developing the capacity of embodying and physically articulating within an artistic dialogue. The other pole of communication is often different and varies both culturally and economically. The term embodiment, encompasses this complex mode of approaching the art of the text. The actor's capacity to embody involves their availability to build a physical connection with any type of spectator and to preserve the message of the dramatic text authentically. During the last few years, the connection between body and mind within the actor's art has been analysed both by neurologists as well as by theatrical theoreticians and practitioners.

Rick Kemp mentions, in his work Embodied Acting, that what leads to the consolidation of a dramatic character is this very process of connecting the mental ' $\mathrm{I}$ ' with the body. The theatre actor and the director refer to the physical instruments of the actor as means of activating the creation process. He concludes that "imagination is much more easily stimulated through physical activity." (Malaev-Babel, 2011) Embodying involves the approach of creativity through the means of senses, and thus the ability is developed to tell a story both through the means of the body and the word. One example of good practice is given by Ariane Mnouchkine and Theatre du Soleil, who together with their theatre company create internationally-renowned theatre shows. 
Helen Richardson states, with regards to Mnouchkine, that "her methodology is rooted in the momentary requests and in her own intuitive way of understanding the creative potential of the actor situated on the edge of the unknown." (Hodge, 2010) The proposed method makes use of the physical and mental availability of the actor and thus attains a high level of physical virtuosity and theatrical involvement.

The manifestation of physical theatre is ever evolving and needs academic support concretized in the phrasing of various theories about the body and acting. If written theatre, the dramatic script, is recognised by literature, the body of the actor has become, during the last decade, the subject of analysis with a view to constructing a work method which encompasses theatrical practices which are not sustained by verbal language, but by the corporeal interpretation of the actor. Along with the emergence of theatre companies which create shows focused on non-verbal language, the academies in the field begin to introduce movement classes within the study of the actor's art. These classes are different from the dance or ballet ones. Physical availability, the connection between the movement of the body and the thought are practised during the classes of stage expressivity, contact improvisation, and non-verbal communication. François Delsarte puts forward a system of actor's training, both in Great Britain, as well as in the US, ever since the beginning of the 20th century. Michael Sanderson describes said training as "a system of physical exercise which is valuable in particular for relaxing the body; giving flexibility to the movement and eliminating part of the everyday tension" (Desmonds, 1967). This set of exercises has a crucial significance in the case of participants who come from a rigid social background, where their body is not in direct communication with emotions.

Learned, inherited, general behaviour generates a series of mechanisms which, in the case of the actor's art, are not the central focus. Through physical exploration, we seek the discovery of corporeal differences which give specificity to both life and the art of theatre. Through physical training, playing, one can easily trace the limits between what is the freedom of creation and the perimeter within which it manifests itself without seeking specific words or lengthy explanations. In the workshop, certain behavioural rules are agreed upon by the group, as well as rules for approaching the actor's art. These function within the workshop, as well as in the personal life of the actors, which helps shape their personality and accentuate their primal instincts. Physical plasticity leads to the training of the capacity to concentrate one's attention, of empathy, of memory, and more. 
Interhuman communication has in fact been a major preoccupation of those who tackled issues of linguistics, socio-linguistics, social psychology and sociology. Undergoing the act of communication depends on the interaction of several factors. On the one hand, this involves an estimation of the social situation in which communication takes place, an evaluation and a selection of the elements that make it up, which are directly linked to the speaker's cultural accomplishment, their personal data and the complete or brief information that they have on the interlocutor. On the other hand, it includes the emergence of the process of selection from the total of the linguistic options available those that are appropriate to the situation in which the speaker finds themselves and their intentions. Thus, what becomes imperative is the approach of the analysis of the ensemble of roles that a speaker can play, as well as the characteristics of certain communities. By role we must understand the functional way of acting in a certain society and in a certain context. An individual that communicates can fulfil several roles; they can be, in turn, parent, teacher, friend, pedestrian, actor, politician - orator, diplomat, etc. Roles have certain characteristics referring to gestures, mimics, dress, and above all, verbal behaviour.

The ensemble of communication roles in a community are considered to be the matrix of communication; what corresponds to this are the functional codes and sub-codes within the matrix of communication. By codes and sub-codes, we also understand different languages used within multilingual communities, as well as the senses of some words or syntagma used in certain situations in which the speaker finds themselves; their deciphering is the task of the listeners.

In sociology and social psychology, communication processes are considered to fundamentally be social instruments. Communication, as an exchange of messages with specific meanings, depends decidedly on the nature of shared meanings, on the motives and effects of this transaction. It is unanimously decided that a communication is emitted with a very precise purpose and that most times, it follows the emergence of certain changes in the behaviour, attitudes, representations and knowledge of the individual and group involved. This purpose depends on a few factors, though: the situation of the individual or the group, the spontaneous effect of deciphering messages (and the reaction of that or those who listened). What's more, the quality of the answers of those who listened can generate changes in the area of the conveyed messages. Strictly technically, one can say that the name communication can be given to any message exchange (verbal, gestural, attitudinal) starting from one point (the emitter) and directed 
towards another (a receiver). So, there is communication where (at a certain time, in a certain place) there is an exchange of meanings from a unanimously accepted area. This data will be closely analysed in order to transpose all this exchange of information through the use of the communication channel which is the body of the actor. Theatre is an art that is based firstly on direct, lucid, and diverse communication. In the present work, we analyse the echo of the word on the body, just like we look for the discovery and demonstration of the necessity of the word following the physical action and the corporeal discourse, and not the other way around. Thus, the actor learns to calibrate the time needed to convey an idea and uses their whole being and plays with forces that are beyond words.

The belief of the cognitive linguist David McNeill is that "gesture and language are equal in the process of communication of the senses" (Kemp, 2012). The researcher, even though not interested in the theatrical manifestation, emphasizes the fact that the exclusion of the corporeal component in the process of communication, practically a formula that has already become tradition, is as though the individual were ignoring half the signals that are sent and at the same time half the brain. The whole corporeal system contributes to the conveying of information. In the case of the applying of this syntagma in the process of approaching the actor's art, a lack of physical involvement in the process of creation and representation can be interpreted as an incorrect way of the actor of understanding their profession. The effect of the written and spoken language is that of fragmenting and uniformizing the meaning. McNeill proposes reading the language of gestures with a view to eliminating this fragmentation. As soon as the drama student of the acting department begins to discern the mechanisms of constructing the dramatic character, they also discover the fact that in many situations the spoken language cannot be completely sustained. Thus, what is imposed is the adding, on top of the structure of the dramatic script, of the gesture, the corporeal involvement. The actor's art consists of their capacity to transform the fragments written into thoughts which appear to be created spontaneously. In the written language, the fragmentation of meanings is not mediated by physical action, and when the language is spoken, the meaning can be strengthened or changed by the gesture.

\section{Conclusion}

In the contemporary world, countless systems of communication are integrated which are subject to interpretation. Spoken language can be interpreted differently by 
people from different cultural contexts; that is why, through the training proposed in the present research, the actor can communicate and interact freely, without fear of being misunderstood through body language. McNeill mentions the fact that gestures are different to words, since they are multidimensional and present complex meanings without being subject to fragmentation and uniformization. Gestures are global and summarizing, never hierarchizing. If language can create differentiated structures, gestures used in real communication create by actors are universal. What is followed is the development of a work process through which the actor can build their own art, and through the use of interior resources, become capable of surviving and adapting to new cultural and technical transformations. own a-temporal artistic and functional manifestation in any space of the contemporary world.

Norbert Elias, in the analysis of the civilising process of the world, says that "in what we call the modern era, people have reached a level of self-detachment." (Norbert, 2002) This allows the individual to place themselves in an objective position, where the process of knowing is controlled and detached. The contemporary actor must be prepared to activate in various areas of interest. The research of the body in the actor's art does not merely involve the analysis of theatrical elements, but also those of behavioural nature. The analysis of the way in which an individual appeal to the corporeal dimension in order to develop, to interact with people and new spaces, is essential during the first stages of formation of the actor. The way in which the individual body has been treated throughout social and technical progress allows the actor to form their own image about the way in which they must treat their body and can foresee the following stages of transformation of the faiths in relation to the idea of bodily identity in the artistic act. Cultural differences impose different attitudinal differences. This aspect must be carefully analysed in order to discover the cultural dimension of corporal language as it relates to the work of the universal actor. If one assumes that the theater is a system of signs, then the actor is the central pillar of this equation. The development of a training model focused on the physical component of the actor as a means of unlocking the psychological and bodily creative springs, has proven to be a necessity in the past that has become rather acute today. Jiri Veltrusky, author of several studies on theatrical semiotics, claims that "the figure of the actor's is the dynamic unit of an entire set of signs (...). The important thing is for the actor to centralize the senses" (Aston \& Savona, 1991), this being made possible by their actions, 
which can replace words. The actor can be regarded as a text converter that, through their art, connects sets of languages in order to communicate universal messages.

Theatre is not a necessity of life, but a gift. The art of theatre expresses the picture of life to which a series of elements are added, in the form of a seed of wonder, impossible, extraordinary. The work of art, says Martin Heidegger, "puts something else on display, it reveals a different thing: it is an allegory. In the work of art, another thing made is put together by Something Else. (...) The work of art is a symbol" (Heidegger, 1982).

\section{References:}

Aston, E., Savona, G. (1991). Theatre as a sign-system. A Semiotics of Text and Performance. London, New York: Routledge.

Barba, E. (2003). A Paper Canoe. Unitext.

Brook, P., Murray, S., Keefe, J. (2016). Physical Theatre. A Critical Introduction. London, New York: Routledge.

Desmond, M. (2002). People watching. The Desmond Morris guide to body language. Vintage.

Desmonds, M. (1967). The Naked Ape. A Zoologist's Classic Study of the Urban Animal. Jonathan Cape Ltd.

Heidegger, M. (1982). The Origin of the Work of Art. Univers. Bucharest.

Hodge, A. (2010). Actor Trainig. London, New York: Routledge.

Kemp, R. (2012). Embodied Acting. What neuroscience tells us about performance. London, New York: Routledge

Malaev-Babel, A. (2011). The Vakbtangov Sourcebook. London: Routledge.

Martha, E. (2009). A brief history of somatic practices and dance: historical development of the field of somatic education and its relationship to dance. Journal of Dance \& Somatic Practices, 1.

Norbert, E. (2002). The Civilizing Process. Translated by Monica-Maria Aldea. Iaşi: "Polirom" Publishing House.

Ralea, M. (1972). Lectures on Aesthetics. Bucharest: Științifică.

Sanderson, M., Evans, M. (2009). Movement Training for the Modern Actor. London, New York: Routledge. 